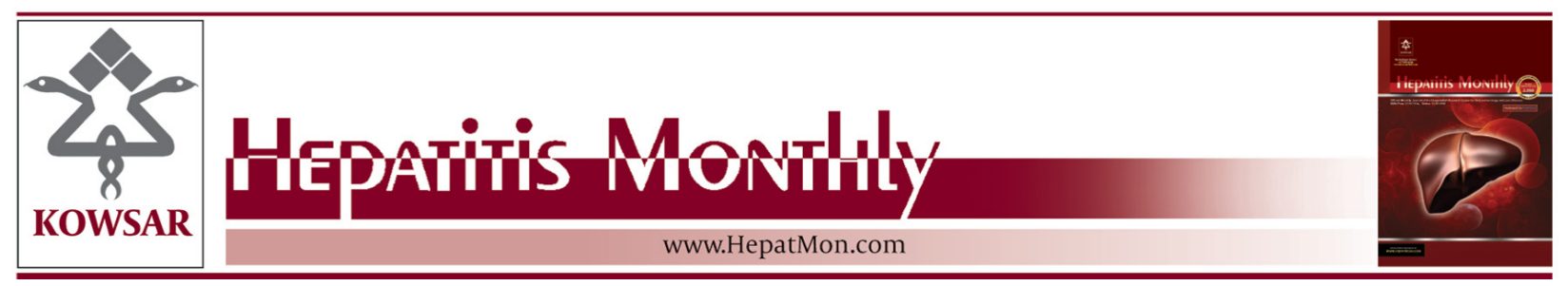

\title{
Hepatitis B Viral DNA Among HBs Antigen Negative Healthy Blood Donors
}

\author{
Maryam Vaezjalali ${ }^{1,2}$, Shabnam Rashidpour ${ }^{3}$, Hanieh Rezaee ${ }^{2}$, Bashir Hajibeigi ${ }^{4}$, Majid \\ Zeidi $^{4}$, Latif Gachkar ${ }^{1}$, Shadi Aghamohamad ${ }^{2}$, Ronak Najafi ${ }^{2}$, Hossein Goudarzi ${ }^{1,2,}$ \\ ${ }^{1}$ Infectious Diseases and Tropical Medicine Research Center, Shahid Beheshti University of Medical Sciences, Tehran, IR Iran \\ 2 Department of Microbiology, Faculty of Medicine, Shahid Beheshti University of Medical Sciences, Tehran, IR Iran \\ ${ }^{3}$ Department of Immunology, Faculty of Medicine, Shahid Beheshti University of Medical Sciences, Tehran, IR Iran \\ ${ }^{4}$ Blood Transfusion Research Center, High Institute for Research and Education in Transfusion Medicine, Tehran, IR Iran
}

${ }^{*}$ Corresponding author: Hossein Goudarzi, Department of Microbiology, Faculty of Medicine, Shahid Beheshti University of Medical Sciences, Velenjak St., Tehran, IR Iran. Tel.: +98-2123872556, Fax:+98-2122439964, E-mail: Hgoudarzi@sbmu.ac.ir.

\begin{abstract}
A B S T R A C T
Background: Presence of occult hepatitis B infection (OBI) renders HBs antigen (HBsAg) undetectable by ELISA. Therefore it is valuable to evaluate the frequency of $\mathrm{OBI}$ among healthy blood donors to improve and perhaps change the strategies of blood screening to reduce the risk of HBV transmission.

Objectives: The aim of this study was to determine the presence of HBcAb and HBVDNA among Iranian HBsAg negative healthy blood donors who donated their blood to the Tehran Blood Transfusion Center during 2011.

Patients and Methods: 1000 serum specimens negative for HBsAg, HCV antibody and HIV antibody were collected from healthy blood donors and tested for HBcAb. Presence of hepatitis B viral DNA was checked in HBcAb positive samples by nested PCR with two sets of primers to amplify part of HBV S gene.

Results: There were 64 women and 936 men in the population under study. The mean \pm SD age of the donors was $38 \pm 11$ years. 80 out of 1000 samples (8\%) were found to be positive for HBcAb. HBV DNA was detected in $50 \%$ of HBcAb positive specimens. The mean \pm SD age of donors without HBV DNA was $37.7 \pm 10.5$ years and for donors with HBV DNA was $40.9 \pm 11.2$ years $(P=0.05)$.

Conclusions: $\mathrm{OBI}$ was prevalent among $50 \%$ of $\mathrm{HBcAb}$ positive healthy blood donors. The frequency of positive $\mathrm{HBcAb}$ among healthy $\mathrm{HBs} A g$ negative blood donors was comparable to previous studies reported from Iran. On the other hand, the frequency of HBV DNA in HBsAg negative blood donors was higher than previous reports.
\end{abstract}

Keywords: Hepatitis B virus; Blood Donors; Polymerase Chain Reaction; Hepatitis B Surface Antigens

Copyright @ (2013, Kowsar Corp.; Published by Kowsar Corp.

Article type: Research Article; Received: 25 Jun 2012, Revised: 15 Jul 2012, Accepted: 31 Jul 2012; DOI:10.5812/hepatmon.6590

Implication for health policy/practice/research/medical education:

This study can be helpful for updating our knowlege about Occult Hepatitis B infection among HBs antigen negative blood donors. However the risk of HBV transfusion transmission is possible among them. Therefore, utilizing sensitive molecular techniques is recommended to ensure about safety of donated blood units.

Please cite this paper as:

Vaezjalali M, Rashidpour S, Rezaee H, Hajibeigi B, Zeidi M, Gachkar L, et al. Hepatitis B Viral DNA Among HBs Antigen Negative Healthy Blood Donors. Hepat Mon. 2013;13(3):e6590. DOI: 10.5812/hepatmon.6590

Copyright @ 2013, Kowsar Corp.; Published by Kowsar Corp.

This is an Open Access article distributed under the terms of the Creative Commons Attribution License (http://creativecommons.org/licenses/by/3.0), which permits unrestricted use, distribution, and reproduction in any medium, provided the original work is properly cited. 


\section{Background}

Infection with hepatitis B virus (HBV) may lead to acute, chronic and sometimes occult infection. HBV has different endemicity rates in the world. In the Middle East, some countries experience high infection rates for HBV infection (Oman and Yemen) while some other countries (Iran and Pakistan) perceived low endemicity for HBV infection (1). The prevalence of occult hepatitis B infection $(\mathrm{OBI})$ is variable depending on different endemicity of $\mathrm{HBV}$ infection in the populations where the relevant study has been done, on different samples (liver specimen or serum) to detect HBV DNA, and on different assays that have been utilized in the study (2). Basically, OBI is characterized by the presence of HBV DNA in the serum of HBsAg negative individuals with serological markers of previous infection such as HBcAb (3). Therefore when using available ELISA tests, there is still a potential risk for transmission of HBV infection in the phase of OBI through blood transfusion. This potential can be avoided if more sensitive tests and preferentially molecular tests are done in endemic regions of this infection. Many recipients of blood products have chronic congenital or acquired diseases and most of them are immunosuppressive to some extent. HBV transmission through transfusion among these hosts may result in severe type of hepatitis B disease in comparison with a normal host. On the other hand, researchers from India (4) and Taiwan (5) have identified OBI as the major cause of HBV transmission through transfusion. Interestingly in both of these countries the incidence of post transfusion hepatitis B is still anything but negligible. HBsAg ELISA test is the only test for donor screening in many countries. HBcAb with consistent nucleic acid tests (NAT) may be a helpful test to diagnose possible OBI (6). Some researchers believe that in endemic regions where the prevalence of $\mathrm{OBI}$ is a major concern, a more appropriate method like HBV NAT is needed to ensure the safety of blood products (7). The cost of NAT assays for HBV detection together with the economical statues of $\mathrm{HBV}$ endemic countries are obstacles to employ nucleic assays for blood screening in these countries (8). It is extremely valuable to determine the prevalence of OBI among healthy blood donors to estimate the chance of HBV transmission through blood transfusion and then assess the need to improve and even change the strategies of pre-donation screening to reduce the risk of HBV transmission (9). Iran with a 3\% prevalence of HBsAg was previously an intermediate endemic country for HBV infection. Since the adoption of routine HBV neonatal vaccination from 1993, it is estimated that HBV endemicity has decreased, reaching around $1.7 \%$ (10). Nevertheless, the reported prevalence of OBI, especially among healthy blood donors, has been fluctuating among various studies in Iran. Part of this difference can depend on the sensitivity and specificity of the assays which have been used in these studies to detect HBV infection. Since a commercial, standardized and valid tech- nique is not available to diagnose OBI, nested PCR method with specified different primers will be useful.

\section{Objectives}

The current study aimed to determine the presence of HBcAb and HBV DNA among Iranian HBsAg negative healthy blood donors who donated their blood to the Tehran Blood Transfusion Center during 2011.

\section{Patients and Methods}

\subsection{Population}

1000 serum samples were obtained from apparently healthy blood donors by the Tehran Blood Transfusion Center offices during November 2011. The inclusion criteria were negative result for HBsAg, HCV antibody and HIV antibody ELISA tests. The sample size formula resulted in 909 samples for the study. Considering an attrition rate of $9 \%$ (because of laboratory / genetic examinations), the required sample size will be about 1000 for the study.

\subsection{Detection of Serologic Markers}

$\mathrm{HBcAb}$ was screened in the samples by ELISA kit (bioELISA anti HBc, Biokit, Barcelona, Spain).

\subsection{Detection of Hepatitis B Viral DNA}

Following serological tests, DNA was extracted from $200 \mathrm{ul}$ of donor HBcAb positive serum by High Pure viral nucleic acid kit (Roche, Germany). Nested PCR was done on $5 \mathrm{ul}$ of DNA extracted from HBcAb positive samples, $10 \mathrm{ul}$ of BIONEER PCR master mix (BIONEER, S.Korea) and two pairs of primers $(25 \mathrm{pmol})$ which were designed to amplify all genotypes of HBV as described previously by Jazayeri et al. (11). HBV genome which was derived from an HBV chronic carrier patient was used as positive control. Distilled water was used as blank control to check material contamination. Lack of contamination was guaranteed by positive and blank controls in each round of nested PCR. For both rounds of nested PCR, DNA samples were denatured at $95^{\circ} \mathrm{C}$ for $14 \mathrm{~min}$ and were subjected to 40 cycles $\left(94^{\circ} \mathrm{C}\right.$ for $1 \mathrm{~min} ; 55^{\circ} \mathrm{C}$ for $1 \mathrm{~min} ; 72^{\circ} \mathrm{C}$ for $\left.90 \mathrm{sec}\right)$ followed by $72^{\circ} \mathrm{C}$ for $10 \mathrm{~min}$ at final extension in an Eppendorf Thermal Cycler PCR (11). After electrophoresis of PCR products in $1 \%$ agarose gel, dyed with ethidium bromide and visualized in UV transilluminator, qualitatively positive samples were reported as OBI cases.

\subsection{Statistical Analysis}

SPSS vs. 16 software was employed to analyze the data. Categorized variable were analyzed using Chi Square or Fisher exact tests as appropriate. Numerical variables were analyzed using independent samples t test. Statistical level of significance was considered at $P<0.05$. 


\section{Results}

1000 blood Samples were collected from 64 (6.4\%) women and 936 (93.6\%) men. The mean \pm SD age of the studied population was $37.7 \pm 10.5$ years. Donation frequency range was 1-92 times (mean: 5.67). 80 positive cases for HBcAb were detected ( 7 women and 73 men) which were comparable to results from other countries (Table). Male gender was observed in $91 \%$ of HBcAb positive donors. The mean \pm SD of donation frequency in HBcAb positive donors was $5.9 \pm 4.8$ and in HBcAb negative donors was
$5.7 \pm 5.9(P>0.05)$. The mean \pm SD of age for HBcAb positive donors was $40.4 \pm 10.9$ years and for HBcAb negative donors was $37.6 \pm 10.5$ year $(P>0.05)$. HBV viral DNA was detected in $4 \%$ of blood donors and in $50 \%$ of $\mathrm{HBcAb}$ positive donors (1 woman and 39 men). The mean \pm SD of age for $\mathrm{HBcAb}$ positive donors without HBV DNA was $37.7 \pm$ 10.5 years and for $\mathrm{HBcAb}$ positive donors with HBV DNA was $40.9 \pm 11.2$ years $(P=0.05)$. To the authors` best knowledge, this was the highest percent of HBV DNA reported from HBcAb positive Iranian blood donors in comparison with other Iranian studies.

Table. Studies on the Prevalence of HBV-DNA in HBcAb Positive Donated Bloods in Asian Countries and the Middle East

\begin{tabular}{|c|c|c|c|c|c|c|c|c|}
\hline Country & Year & $\begin{array}{l}\text { Number of } \\
\text { Blood Samples }\end{array}$ & $\begin{array}{l}\text { Serological } \\
\text { Test }\end{array}$ & Molecular Test & HBCAb,$+ \%$ & Viral DNA $+^{\mathrm{a}}$, \% & OBI $^{\mathrm{b}}$,\% & Reference \\
\hline South Korea & 2008 & 12461 & $\begin{array}{l}\text { ECL } \\
\text { immunoassay }\end{array}$ & $\begin{array}{l}\text { multiplex Real } \\
\text { time PCR kit }\end{array}$ & 13.5 & 0.1 & 0.016 & (27) \\
\hline India & 2010 & 12232 & ELISA & NA & 0.12 & NA & NA & (28) \\
\hline India & 2012 & 94247 & ELISA & ID NAT & 10.22 & 0.15 & 0.01 & (29) \\
\hline Pakistan & 2005 & 966 & ELISA & $\begin{array}{l}\text { nested PCR with } \\
\text { a commercial kit }\end{array}$ & 17.28 & 3 & 0.5 & (30) \\
\hline Turkey & 2006 & 1196 & ELISA & $\begin{array}{l}\text { Pooled Real Time } \\
\text { PCR }\end{array}$ & 15 & 0 & 0 & (31) \\
\hline Turkey & 2007 & 1000 & ELISA & $\begin{array}{l}\text { Real Time PCR } \\
\text { kit }\end{array}$ & 20 & 0 & 0 & (32) \\
\hline
\end{tabular}

Abbreviations: NA, not available; ID NAT, individual NAT; ECL, electro chemiluminescence; OBI, occult hepatitis B infection.

a Within HBcAb positive patients

$\mathrm{b}$ Within total population studied

\section{Discussion}

In this study, serum samples of HBsAg negative healthy blood donors were collected from 1000 healthy blood donors and HBcAb of these samples were examined by ELISA assay. $91 \%$ of $\mathrm{HBcAb}$ positive donors were male and only $9 \%$ were female which was not much different from the gender distribution of the blood donor population. A positive relationship was observed between $\mathrm{HBcAb}$ positivity and age of the donors and also with HBV DNA positivity. This means that older persons possibly live with HBV for a longer period which can provide an opportunity for the virus to change its genome or set balance with the host immunity and live persistently with its host. Then it can be suggested that HBV infected Iranian patients have been infected in the early decades of their lives. This is in consistent with other studies which had suggested intra familial transmission of HBV as the important way for HBV transmission in Iran $(12,13)$. The results of this study revealed that half of $\mathrm{HBcAb}$ positive samples were also positive for HBV DNA. Therefore a positive relationship between $\mathrm{HBCAb}$ positivity and existence of HBVDNA was distinguished. The current research data on $\mathrm{HBcAb}$ prevalence were consistent with previous data obtained from other studies in Iran and from other countries in the Middle East. (Table) On the other hand, the relative frequency of patients with positive viral DNA was considerably higher than previous studies in Iran. One important difference was that it was the first time in Iran that HBV DNA in apparently healthy blood donors was detected by nested PCR, while in previous researches singleround PCR was employed to detect viral DNA. It should be emphasized that, at present, the gold standard test for OBI diagnosis is "homemade nested PCR" technique with at least two different sets of primers $(7,14)$. Single-round PCR or Real time PCR was the only method which was used in previous Iranian studies on OBI among healthy blood donors. Since viral load among OBI people can be low or fluctuating, nested PCR with high sensitivity is a useful technique to detect $\operatorname{HBV}$ genome $(7,15)$. There are some studies about OBI among healthy blood donors in which nested PCR has been used as a critical method to detect HBV genome. Each of these studies has reported a different prevalence of OBI. It seems that HBV endemicity and laboratory methods to detect the infection are the most important factors which lead to these controversial results.

In a case report from Brazil, viral DNA was detected in an HBsAg and HBcAb negative blood donor by nested PCR. The researchers emphasized the importance of nested PCR and recommended NAT to screen donated blood units $(16,17)$. In Iran, Delavari et al. studied 1535 blood do- 
nors in Kerman in 2010. They reported that 8 percent of the blood samples negative for HBsAg, were positive for HBcAb. HBV DNA was detected in $29.7 \%$ of HBcAb positive samples by Real Time PCR (18). In another study done in Rasht, the prevalence of HBcAb positive samples was $3.8 \%$ and only one case was positive for viral DNA (19). In Arak, Sofian et al. reported that $2.1 \%$ of blood donors were $\mathrm{HBcAb}$ positive. They did not detect any viral DNA in the population under study (20). The authors noted that Arak province is a low prevalence region for HBV infection. They did not however provide any proof of this claim. Jafarzadeh et al. reported that 5.2\% of blood donors in Rafsanjan in 2008 were HBcAb positive and detected HBV DNA in $28.6 \%$ of the individuals (21). In Isfahan, the prevalence of HBcAb and viral DNA in HBcAb positive samples were reported $8 \%$ and $11.3 \%$ respectively (22). Finally in another study in Shiraz done in $2004,6.5 \%$ of blood donors were positive for HBcAb and HBV DNA was detected in $12.2 \%$ of the samples (23). Reports from other countries such as Pakistan, South Korea, and Turkey reveal the presence of viral DNA in healthy blood donors with positive $\mathrm{HBcAb}$ (Table). The results of studies on the frequency of $\mathrm{HBCAb}$ and viral DNA positivity from some Asian countries have been summarized in Table. The differences in results of studies in Iran can be partly explained by different endemicity rates of HBV infection in different regions of Iran. The current study has been done in the capital of Iran which is a mixture of different Iranian ethnicities. The data revealed that the relative frequency of $\mathrm{HBcAb}$ and/or DNA positive blood donors has not reduced over this six-year period and has even increased. It seems that more radical changes in screening system of blood donation or HBV vaccination have to be done to solve this old problem in Iran. Studies in Iran on OBI among healthy blood donors suggest that at least HBcAb screening of blood donors may reduce the risk of HBV transmission through transfusion. In spite of the reduction in the rate of HBV infection after vaccination and improvements in the selection criteria for blood donors, transmission of HBV infection by transfusion still occurs specially in developing countries. Blood screening procedures are dependent on HBV endemicity and economic conditions of each country. Some countries like Iran (21) and India (6) only use HBsAg test for blood screening, others like Brazil also use HBcAb ELISA test to ensure blood safety (17). It seems that in countries with high or intermediate prevalence of hepatitis B, HBcAb test may lead to limited blood supplies (6) and it will be better if only HBcAb IgM and not the total HBcAb test is used to screen donated blood units (24). With commercial HBcAb ELISA kits, the total HBcAb (IgM + IgG) is measured. In the case of HB$c A b$ positivity, different scenarios are predicted. One of them is convalescent of hepatitis B disease and another is chronic infection with HBV. If donor's HBcAb IgM is positive, it means that he is currently infected with HBV and this blood sample is hence infected as well. The common tests which are usually used to detect HBsAg are conven- tional ELISA and sometimes molecular tests like PCR. In OBI patients, the aforementioned tests have low efficacy because of undetectable HBsAg due to possible viral mutations or imperfect immune responses of the host. Some OBI cases stay uncovered by these assays and have the potential ability to spread viral infection and be a source of HBV transmission through transfusion (25). One of the suggestions of this study is to follow up the people who received donated blood from OBI patients to observe the effect of this donation on their health and evaluate the reactions of their immune system too. More researches should be done in the future to detect and evaluate viral mutations and genetic factors of recipients' immune system in Iran to clarify the interactions of the virus and the host immune system in different regions with various endemicity rates. And finally as it was confirmed in previous studies in Iran, single round-PCR test is not reliable enough to detect all OBI cases and more sensitive molecular tests such as nested PCR are needed to be done to increase the reliability of the screening. It seems that combination of molecular tests and $\mathrm{HBcAb}$ is preferable to HBsAg and HBcAb screening (26). The current study emphasized that OBI was prevalent among $50 \%$ of $\mathrm{HBCAb}$ positive healthy blood donors. By the "in house nested PCR" more OBI cases can be detected among healthy blood donors in comparison with previous studies in Iran. This matter results in to be more careful about the risk of HBV transmission through transfusion. As Iran was originally an intermediate HBV endemicity rate, which had been reported before $\mathrm{HBV}$ vaccination, it seems that HBsAg is not enough to reject infected blood donors. Furthermore, it is highly recommend that $\mathrm{HBcAb}$ test can reduce the risk of HBV transmission through transfusion.

\section{Acknowledgements}

The authors would like to acknowledge their gratitude to the Tehran Blood Transfusion Center for their kind assistance in this study, to Dr. Davood Yadegari for his consistent support and Dr. Amir H. Kashi for his assistance in the preparation of this manuscript. They also wish to thank Aidin Shahi, Maryam Noori, Elahe Karimi Ravesh, Fatemeh Ashrafian, Narjes Shokatpour for providing blood samples and performing HBcAb ELISA tests in this study.

\section{Authors' Contribution}

All authors were involved in all steps of manuscript preparation.

\section{Financial Disclosure}

None Declared.

\section{Funding/Support}

This project has been done by the grant number 422/259 from the Infectious Diseases and Tropical Medicine Re- 
search Center, Shahid Beheshti University of Medical Sciences, Tehran, Iran. The authors do not have a financial relationship with any commercial entity that has an interest in the subject of this manuscript.

\section{References}

1. Alavian SM, Fallahian F, Lankarani KB. The changing epidemiology of viral hepatitis B in Iran. J Gastrointestin Liver Dis.2007;16(4):403-6

2. Chemin I, Trepo C. Clinical impact of occult HBV infections.J Clin Virol.2005;34 Suppl 1:S15-21

3. van Hemert FJ, Zaaijer HL, Berkhout B, Lukashov VV. Occult hepatitis B infection: an evolutionary scenario. Virol J.2008;5:146

4. Saraswat S, Banerjee K, Chaudhury N, Mahant T, Khandekar P, Gupta RK, et al. Post-transfusion hepatitis type B following multiple transfusions of HBsAg-negative blood. J Hepatol.1996;25(5):639-43

5. Liu CJ, Lo SC, Kao JH, Tseng PT, Lai MY, Ni YH, et al. Transmission of occult hepatitis B virus by transfusion to adult and pediatric recipients in Taiwan.J Hepatol.2006;44(1):39-46

6. Datta S, Banerjee A, Chandra PK, Chakraborty S, Basu SK, Chakravarty $R$. Detection of a premature stop codon in the surface gene of hepatitis B virus from an HBsAg and antiHBc negative blood donor.J Clin Virol.2007;40(3):255-8

7. Raimondo G, Pollicino T, Cacciola I, Squadrito G. Occult hepatitis B virus infection. J Hepatol.2007;46(1):160-70

8. Vitale F, Tramuto F, Orlando A, Vizzini G, Meli V, Cerame G, et al. Can the serological status of anti-HBc alone be considered a sentinel marker for detection of occult HBV infection? J Med Virol.2008;80(4):577-82

9. Dufour DR. Hepatitis B surface antigen (HBsAg) assays--are they good enough for their current uses? Clin Chem.2006;52(8):1457-9

10. Poorolajal J, Majdzadeh R. Prevalence of chronic hepatitis B infection in Iran: a review article.J Res Med Sci.2009;14(4):249-58

11. Jazayeri MS, Basuni AA, Cooksley G, Locarnini S, Carman WF. Hepatitis $B$ virus genotypes, core gene variability and ethnicity in the Pacific region.J Hepatol.2004;41(1):139-46

12. Ranjbar M, Golzardi Z, Sedigh L, Nekoozadeh S. Intrafamilial seropositivity of hepatitis in patients with hepatitis $\mathrm{B}$ and $\mathrm{C}$ virus in hepatitis clinic in Hamadan, Iran. Ann Hepatol.2012;11(1):32-6

13. Toukan AU. Hepatitis B in the Middle East: aspects of epidemiology and liver disease after infection. Gut.1996;38 Suppl 2:S2-4

14. Conjeevaram HS, Lok AS. Occult hepatitis B virus infection: a hidden menace? Hepatology.2001;34(1):204-6

15. Yuan Q, Ou SH, Chen CR, Ge SX, Pei B, Chen QR, et al. Molecular characteristics of occult hepatitis B virus from blood donors in southeast China.J Clin Microbiol.2010;48(2):357-62

16. Aguiar JI, Aguiar E, Paniago A, Cunha R, Galvao L, Daher R. Prevalence of antibodies to hepatitis B core antigen in blood donors in the middle West region of Brazil. Mem Inst Oswaldo Cruz.2001;96(2):185-7
17. Almeida RP, Cardoso DD. Detection of HBV DNA by nested-PCR in a HBsAg and anti-HBc negative blood bank donor. J Clin Virol.2006;36(3):231-4

18. Delavari M, Shahabinejhad N, Renzaho A, Zahedi M, Owhadi AR Frequency of Anti-HBc \& HBV DNA detection in blood donors of Kerman province, Iran. Jblood disorders transfusion.2011;2(1):1-4

19. Khamesipour A, Amiri ZM, Kafiabad SA, Saadat F, Mansourghanaei F, Esteghamati AR, et al. Frequency of hepatitis B virus DNA in anti-HBc positive, HBsAg negative blood donors in Rasht, northern Iran. Transfus Apher Sci.2011;45(2):195-7

20. Sofian M, Aghakhani A, Izadi N, Banifazl M, Kalantar E, Eslamifa A, et al. Lack of occult hepatitis B virus infection among blood donors with isolated hepatitis B core antibody living in an HBV low prevalence region of Iran. Int J Infect Dis.2010;14(4):e308-10

21. Jafarzadeh A, Arababadi MK, Pourazar MMA. Occult hepatitis B virus infection among blood donors with antibodies to hepatitis B core antigen. Acta Medica Iranica.2008;46(1):27-32

22. Pourazar A, Salehi M, Jafarzadeh A, Arababadi MK, Oreizi F, Shariatinezhad K. Detection of HBV DNA in HBsAg negative normal blood donors. III.2005;2(3):172-6

23. Behzad-Behbahani A, Mafi-Nejad A, Tabei SZ, Lankarani KB, Torab A, Moaddeb A. Anti-HBc \& HBV-DNA detection in blood donors negative for hepatitis B virus surface antigen in reducing risk of transfusion associated HBV infection. Indian J Med Res.2006;123(1):37-42

24. Jeremiah ZA, Idris H, Ajayi BB, Ezimah AC, Malah MB, Baba MM. Isolated anti-HBc-IgM antibody among blood donors in the semi-arid region of Nigeria. Hum Antibodies.2011;20(3-4):77-82

25. Yoshiba M, Sekiyama K, Sugata F, Kawamoto Y, Muraoka H, Aoyama M. Post-transfusion fulminant hepatitis B after screening for hepatitis B virus core antibody. Lancet.1992;339(8787):253-4

26. Niederhauser $C$. Reducing the risk of hepatitis B virus transfusion-transmitted infection. J Blood Med.2011;2:91-102

27. Seo DH, Whang DH, Song EY, Kim HS, Park Q. Prevalence of antibodies to hepatitis B core antigen and occult hepatitis B virus infections in Korean blood donors. Transfusion.2011;51(8):1840-6

28. Shastry S, Bhat SS. Prevention of post-transfusion hepatitis by screening of antibody to hepatitis B core antigen in healthy blood donors. Mediterr J Hematol Infect Dis.2011;3(1):e2011062

29. Makroo RN, Chowdhry M, Bhatia A, Arora B, Rosamma NL. Hepatitis B core antibody testing in Indian blood donors: A doubleedged sword! Asian J Transfus Sci.2012;6(1):10-3

30. Bhatti FA, Ullah Z, Salamat N, Ayub M, Ghani E. Anti-hepatits B core antigen testing, viral markers, and occult hepatitis B virus infection in Pakistani blood donors: implications for transfusion practice. Transfusion.2007:47(1):74-9

31. Arabaci F, Oldacay M. Investigation of mutant hepatitis B virus in core antibody seropositive cases of blood donor population. Med Sci.2008;8(3):316-20

32. Findik D, Arslan U, Baykan M. Determination of hepatitis B virus DNA incidence, viral load, and mutations in blood donors with HBsAg and anti-HBs-negative serology and antibodies to hepatitis B core antigen. Eur J Intern Med.2007;18(8):571-5 